\title{
The Nexus Between Financial Failure and Stock Prices: Panel Pedroni, Panel Kao and Panel ARDL Co-Integration Tests in Turkey REITs
}

\section{ABSTRACT}

In today's globally competitive environment, companies must keep up with these competitive conditions to be successful. Failure of companies to show the expected financial performance, fulfil their financial obligations, or reach their financial targets is considered a financial failure or bankruptcy risk. Real Estate Investment Companies or Trusts (REICs or REITs) are capital market institutions that qualify as legal entities and are partnerships in a joint-stock company that provides financing to all kinds of real estate or real estate projects and bring together many investors for the desired real estate. REITs are an essential investment choice that continues its rapid development in Turkey. This study aims to examine the relationships between the ZScores calculated by periods of REIT companies traded in Borsa Istanbul between 2010-2019 and the stock price performances. In the study, primarily Altman Z-Score and Springate S-Score values of companies traded in Borsa Istanbul were calculated with the help of financial ratios. Then, Pedroni and Kao panel co-integration analysis and Dumitrescu-Hurlin panel causality analysis were performed. According to the analysis results, there is a long-term relationship between the financial failure scores of REIT companies and their stock prices. However, a causality relationship was found between the series.

Keywords: Financial Failure; Bankruptcy Risk; REITs; Altman Z-Score; Springate S-Score; Panel Causality Test; Panel Cointegration Test

For citation: Tekin B. The nexus between financial failure and stock prices: Panel Pedroni, Panel Kao and Panel ARDL Co-Integration Tests in Turkey REITs. Finance: Theory and Practice. 2021;25(6):145-164. DOI: 10.26794/2587-5671-2021-25-6-145-164

\section{Связь между финансовой несостоятельностью и ценами на акции: случай с фондами недвижимости (REITs) Стамбульской биржи}

\section{АННОТАЦИЯ}

В сегодняшней глобальной конкурентной среде компании должны соответствовать конкурентным условиям, чтобы быть успешными. Неспособность компаний продемонстрировать ожидаемые финансовые результаты, выполнить свои финансовые обязательства или достичь своих финансовых целей считается финансовым крахом или порождает риск банкротства. Инвестиционные фонды (трасты) недвижимости (REITs) - это институты рынка капитала, юридические лица, которые обеспечивают финансирование всех видов недвижимости или проектов в сфере недвижимости и объединяют множество инвесторов для ее приобретения. Инвестиционные трасты недвижимости в Турции популярны как инвестиционные институты и продолжают быстро развиваться. Целью данного исследования является изучение взаимосвязи между Z-коэффициентами компаний REITs, торгующихся на Стамбульской бирже (Borsa Istanbul, BIST) в период 2010-2019 гг., и ценами на их акции. Рассчитаны значения Z-Score Aльтмана и S-Score Спрингейта компаний, торгующихся на Borsa Istanbul, с помощью финансовых коэффициентов. Проведен панельный коинтеграционный анализ Педрони и Као и панельный анализ причинности Думитреску-Хурлина. Согласно результатам анализа сделан вывод, что существует долгосрочная связь между показателями финансовой несостоятельности REIT-компаний и ценами на их акции. Между этими рядами обнаружена причинно-следственная связь.

Ключевые слова: финансовая несостоятельность; риск банкротства; REITs; Z-коэффициент Альтмана; S-коэффициент Спрингейта; панельный тест причинности; панельный тест коинтеграции

Для цитирования: Tekin B. The nexus between financial failure and stock prices: Panel Pedroni, Panel Kao and Panel ARDL Co-Integration Tests in Turkey REITs. Финансы: теория и практика. 2021;25(6):145-164. DOI: 10.26794/2587-56712021-25-6-145-164

(c) Tekin B., 2021 


\section{INTRODUCTION}

Recently, with the increasing complexity and liberalizing markets, the level of competition and risk factors that drive companies to financial failure has increased. Financial failure is a factor that can affect not only companies and their stakeholders but also the whole economy of the country in which it operates. The country's cumulative risk of financial failure has led to a more in-depth investigation of the issue by researchers, financial analysts, business managers, and business owners. As a result of the studies carried out in this direction, quantitative and qualitative models have been put forward to predict financial failure and bankruptcy before it occurs [1].

Today, the development of technology and the information world has made the competition even more challenging. Under these conditions, businesses that contribute significantly to the development process of countries and international financial markets are also more exposed to the risk of financial failure in the competitive environment brought by globalization. In an environment where competition is so fierce, the most important factors of financial failure in businesses are internal reasons and economic conditions. However, the financial failure of the companies can have a significant negative impact on the economy of the country in which they operate. All parties involved in the business can be adversely affected by the financially unsuccessful business. Business-related parties especially want to get out of such a process with as minor damage as possible. The enterprise in financial failure imposes high costs on all interest groups. Therefore, financial failure should be predicted in terms of enterprise and the whole country [2].

There are various internal reasons such as insufficient working capital, excessive increase in shortterm debts, increased resource costs, unsuccessful budgets and other financial plans, delayed payments, and inability to find financing sources that cause financial failure in the companies [3]. In addition to internal reasons, there are also external reasons that drive companies to financial failures, such as the country's economic growth level, financial or economic crisis or recession periods, inflation rates, high-interest rates, excessively fluctuating exchange rates, the tight monetary policy implemented by the central bank, changes in customer preferences, attitudes and behaviour [4].

By predicting financial failure and responding to this situation as early as possible, the business's financial failure can be minimized. Moreover, investors and lenders can reduce the risk of investment depreciation or failure to collect receivables by considering the risk of financial failure while evaluating the issues of investing in businesses and lending [5]. Accordingly, it is seen in the literature that different estimation methods such as artificial neural networks, logistic regression analysis, cluster analysis, discriminant analysis, fuzzy logic are used in determining financial failure. Furthermore, in detecting financial failure, it is seen that methods such as the Altman Z-Score and Springate S-Score models, which are among the multiple discriminant analysis methods, logistic regression, multi-criteria decisionmaking methods come to the fore.

Within the scope of this study, the relationship between financial failure and share price was investigated based on REITs. As stated by J. Shen [6], there are several reasons for this. The first is that financial failures are observed more intensely in the REIT sector compared to other sectors. So much so that REICs or REITs were highly affected by the financial crises in the Turkish economy in the early 2000s. While losses of up to $70 \%$ were observed in returns, severe losses were experienced in REITs' portfolio and market values [7]. Representatives of REITs established the Real Estate Investors Association (GYODER) ${ }^{1}$ in 1999 to promote and represent the real estate sector, encourage its development, and set standards in quality control and training in the sector [8].

REITs also use more debt financing than firms in other sectors and are subject to regulation. It has to pay a significant portion of its earnings to investors as dividends. In this context, REITs are likely to have a higher distress risk than similar firms in other industries [9]. For the same reasons, stock prices can be expected to be more volatile. Third, there have been significant developments and changes in the REIT sector, such as organizational changes, shifting the large investor base from individual investors to institutional investors, and rapid asset growth. The role of these changes in the interaction between financial failure and stock price is also becoming important [6].

The financial failure or bankruptcy risk, which are the essential topics in the literature, is frequently examined in the Altman Z-Score and Springate S-Score context. In this study, also these methods were used to examine financial failure. However, in this study, the aim is not only to calculate the scores. In this context,

${ }^{1}$ GYODER was founded in 1999 by the representatives of existing real estate investment trusts and those under establishment process in Turkey (REIT). The organization that gathers all sub-industries of the sector under the same roof as "Turkey Real Estate Platform" changed its name in 2013 as "Real Estate and Real Estate Investment Trusts Association" and transformed into a structure that embraces the overall sector (https://www.gyoder.org.tr/en/about-us (accessed on 12.03.2020). 
the relationships between REITs' Z-scores and S-scores and the stock price performance of REITs are examined. The REITs in the scope of this study are traded in Borsa Istanbul continuously between 2010: Q1 and 2019: Q4 and whose data can be fully accessed. In the analysis section following steps were followed:

- First, Altman Z-Score and Springate S-Score values of companies traded in Borsa Istanbul were calculated with the help of financial ratios.

- Second, quarterly stock prices of 18 companies determined for Altman Z-score and 17 companies determined for Springate S-score were obtained from Borsa Istanbul.

- Third, Pedroni, Kao and ARDL Bound panel cointegration analyses and Dumitrescu-Hurlin panel causality analysis were performed.

Analysis results prove that there is a long-term relationship between financial failure scores and stock prices. Furthermore, we determined that there is causality between the series. The main differences of the study from previous studies are as follows:

- This is the first study on the relationship between financial failure and stock price in REITs and carried out in such a broad scope.

- For the first time in the literature, Panel ARDL co-integration analysis, Pedroni and Kao cointegration analysis, and Dumitrescu and Hurlin panel causality analyses were used together.

In the following sections of the study, firstly, REITs and the current situation of the sector in Turkey will be discussed. In the following sections, literature review, data and methodology and findings will be given, and the study will be concluded with the conclusion part.

\section{REITS IN TURKEY}

The construction sector in Turkey has an essential share in the economy and economic growth. Since real estate purchases are seen as an investment tool simultaneously in Turkey, the sector's volume has grown more and more each year. REITs are capital market institutions that qualify as legal entities and are partnerships in a joint-stock company. If the public joint-stock company establishes to operate the portfolio consisting of real estate, real estate projects, rights based on real estate, capital market instrument, and assets and rights determined by the board are called "Real Estate Investment Trusts." Real estate investment trusts have advantages in terms of corporate tax. Regardless of the amount of profit they make, they are not subject to corporate tax in any way and have a $100 \%$ exemption. Therefore, real estate investment trusts allow small investors to generate income from the profits made in this field and to direct the large funds that these investors will create to this sector. In addition, REITs also have objectives such as building real estate necessary for the increasing population, decreasing the informal economy, and increasing the use of capital market instruments. The majority of assets in the financial statements of real estate investment trusts listed on the stock exchange are investment properties [10].

With the development of financial markets, investment instruments and financing alternatives are also increasing. In this context, Real Estate Investment Trusts (REITs) are one of the most important institutional investors in the real estate sector. REITs first started operations in 1961 in Massachusetts (USA). In Turkey, REITs started their activities with legal regulation in 1995. In 1997, the shares of REITs began to be traded on the Borsa Istanbul. The primary duty of REITs is to meet the financing needs of the real estate sector and bring transparency to the market. However, REITs have become a critical capital market institution that enables large-scale real estate projects to be implemented [11]. Currently, there are REITs in 36 countries around the world. In addition, global mutual funds mainly include REITs in their portfolios [11].

REITs sector takes the lead among the other sectors as it acts as such an anchor in the economies of developed and developing countries. However, as in the world, the financing problem in the real estate sector in Turkey constitutes a significant problem. Some real estate projects require too much capital that a single investor cannot handle. Therefore, this obstacle to realizing projects is eliminated by REITs. In this way, the required liquidity is provided through the securitization of real estate. Therefore, REITs have an essential place in the effective use and management of their resources for the stable growth of developed and developing countries [12].

As of the 4th quarter of 2019, the number of REITs traded in Turkey and Borsa Istanbul is 33. While the free float rate of the REIT sector in Turkey is 53\%, stocks in the actual circulation rate are $36 \%$. The total REITs market value is 27 billion 777 million $P$. In 2019 , the total transaction volume was 70 billion 436 million $P$ in the REITs market. According to the residence addresses of the investors, it is seen that most investments are made from the USA $(1,039,357,609 P)$. USA is followed by the United Kingdom $(727,741,216$ P), Netherlands $(287,198,909 P)$, Italy $(135,846,803 P)$ and Bahrain $(127,020,000 P) .{ }^{2}$ The total asset value of

\footnotetext{
${ }^{2}$ GYODER (The Association of Real Estate and Real Estate Investment Company). GYODER Indicator Turkish Real Estate Sector 20194th Quarter Report. 2020: Vol. 19.
} 
REITs traded in Turkey has reached the level of about 12.965 million $€$ as of December 31, 2019. ${ }^{3}$ The sector's return on assets has seen the lowest level since 2011, with $6 \%$ in 2018. The gross profit of REITs in Turkey increased continuously from 2011 to 2018 and rose from approximately 1.6 million $P$ to 5.2 million $P$. Due to the significant increase in the $\$$ exchange rate in the 2014-2018 period, the sector's profitability decreased in $\$$ terms in this period. ${ }^{4}$

Although it is such an essential sector for developing countries such as Turkey, few studies in the literature evaluate the financial failure probability of REITs. Therefore, this study, besides evaluating REITs' financial failures, aims to reveal beneficial results for investors and focus on the relationship between financial failure and stock prices.

\section{THE CONCEPT OF FINANCIAL FAILURE}

Financial failure is defined as the companies not paying their debts on time, declaring concordat, making a loss for three years in a row [13]. According to W.H. Beaver [14], financial failure is the companies' inability to fulfil their due financial debts.

In order to talk about financial failure in a company, at least one of the following situations must exist [15].

1. Cessation of company activities or bankruptcy;

2. The company encounters events such as pledge, execution, and foreclosure;

3. Realization of court processes such as liquidation of the company, appointment of a trustee or restructuring;

4. The company's voluntary agreement on the payment of its due debts.

Companies faced with one of the four situations mentioned above are considered to be financially unsuccessful. Most studies define financial failure as filing for bankruptcy in the literature. That is why bankruptcy comes to mind first when it comes to financial failure. However, bankruptcy is only one of the situations of financial failure, or it is possible to state that financial failure does not only mean bankruptcy [16].

If financial failure cannot be prevented, bankruptcy occurs. This situation indicates that a legal process has been entered into. Unlike financial failure, defining bankruptcy in relevant laws makes this concept more understandable [17]. Bankruptcy occurs when the company's assets cannot meet its debts, and the net

\footnotetext{
${ }^{3}$ European Public Real Estate Association (EPRA). Global REIT Survey 2020.

${ }^{4}$ GYODER (The Association of Real Estate and Real Estate Investment Company). GYODER Indicator Turkish Real Estate Sector 20194th Quarter Report. 2020: Vol. 19.
}

asset of a bankrupt business becomes negative in real terms. However, the loss incurred by businesses is not always expressed as a financial failure. For example, it is estimated that there is a risk of financial failure for the company, although it is not seen as a financial failure if a company makes an intermittent loss one or two times in ten years operating period [18].

\section{ALTMAN Z-SCORE AND SPRINGATE S-SCORE}

Many methods are used in the literature to determine the financial failures of companies, and Altman $\mathrm{Z}$ Score and Springate models are among the most commonly used methods.

\section{Altman Z-Score Model}

Anticipating financial failure and taking necessary measures are very important for the continuity of companies. However, for this purpose, although it is a general opinion, it is not sufficient to examine the tendency of some rates of companies. One of the methods developed due to this deficiency is the Altman Z-Score model. The Altman Z-Score model is a multivariate discriminant analysis used to predict companies' financial failures and bankruptcy risks. The general structure of the Altman model was revealed in 1968, then the model was re-developed for non-public companies in 2000 and then for companies other than manufacturing companies [19].

The Altman Z Score model has highly reliable applications in various areas, including merger and disposal activity, asset pricing and market efficiency, capital structure determination, credit risk pricing, distressed securities, bond ratings, and portfolios [20].

Altman [21] determined many financial ratios that can be used to measure financial failure and stated that among these ratios, those related to company profit, liquidity and solvency should be considered primarily compared to others. However, in the studies carried out in the following period, it has been shown that different ratios may be important. Therefore, no definite conclusion has been reached on this issue. Altman [21] expressed the model with the following equation:

$$
\begin{gathered}
Z=0.012 X 1+0.014 X 2+0.033 X 3+ \\
+0.006 X 4+0.999 X 5
\end{gathered}
$$

$X 1=$ Working Capital /Total Assets,

X2=Undistributed Profit /Total Assets, X3= Profit Before Interest and Taxes /Total Assets, 
X4=BookValue of Equity / BookValue of Total Debts

$$
X 5=\text { Sales } / \text { Total Assets and }
$$

The ranges determined for the Z-Score results obtained from the first equation above are given below:

$$
\begin{gathered}
Z>2.99 \text { is financially successful, } \\
1.8<Z<2.99 \text { is Gray zone and } \\
Z<1.8 \text { is determined as a financial failure. }
\end{gathered}
$$

A Z-Score greater than 2.99 indicates that the company is financially successful, and a lower than 1.8 indicates that the company is financially unsuccessful.

Altman revised the current model by completely re-estimating it in 1983 and substituting the book value of equity for market value. As a result, the revised Z-Score model is expressed by the following model:

$$
\begin{gathered}
Z^{\prime}=0.717 T 1+0.847 T 2+3.107 T 3+ \\
+0.420 T 4+0.998 T 5
\end{gathered}
$$

$T 1=$ Net Working Capital /Total Assets,

T2=Undistributed Profit /Total Assets,

T3= Profit Before Interest and Tax /Total Assets,

T4=BookValue of Equity /Total Debts,

$$
\text { T5=Sales } / \text { Total Assets. }
$$

The ranges determined for the Z'-Score results obtained from the second equation are stated below:

$$
\begin{aligned}
& \text { If } Z>2.9 \text { financially successful, } \\
& 1.23<Z<2.9 \text { is the grey zone, } \\
& \text { If } Z<1.23 \text {, financial failure. }
\end{aligned}
$$

Altman has taken into account public and nonpublic companies in his first two studies. In his last study, he developed a model for companies other than manufacturing companies, and this model is expressed below:

$$
\begin{gathered}
Z "=6.56 X 1+3.26 X 2+6.72 X 3+1.05 X 4 \\
X 1=\text { Net } \text { Working Capital /Total Assets, } \\
X 2=\text { Undistributed Profit /Total Assets, } \\
X 3=\text { Profit Before Tax /Total Assets, }
\end{gathered}
$$

\section{X4=BookValue of Equity /Total Debts.}

The intervals determined for the Z"-Score results obtained from the third equation are given below:

$$
\begin{gathered}
\text { If } Z^{\prime \prime}>2.6, \text { it is financially successful, } \\
\text { If } 1.1<Z^{\prime \prime}<2.6, \text { gray zone, } \\
\text { If } Z^{\prime \prime}<1.1, \text { financial failure. }
\end{gathered}
$$

\section{Springate S-Score Model}

In 1978 L. V. Gordon the Springate S-Score model developed by Springate is the development of the Altman Z-Score model, and the four ratios used in the Altman Z-Score model are weighted with different weights. According to this model, if the S-Score value is less than 0.862 , the company is considered financially unsuccessful or close to bankruptcy [22]. The model is stated below [23]:

$$
\begin{gathered}
\begin{array}{c}
\text { S Score }=(1.03 X 1)+(3.07 X 2)+ \\
+(0.66 X 3)+(0.4 X 4)
\end{array} \\
X 1=\text { Net Working Capital /Total Assets, } \\
X 2=\text { Profit Before Interest and Tax /Total Assets, } \\
X 3=\text { Profit Before Tax /Short Term Debts, } \\
\text { X4 } 4=\text { Net Sales /Total Assets. }
\end{gathered}
$$

If $S<0.862$, the company is considered to be at risk of financial failure or bankruptcy.

\section{LITERATURE REVIEW}

Financial ratios are generally used to examine the success (H.C. Koh [24]; İ. Ege [25]), failure (R. Aktaş [26]; J. Chen [27]; J. Pindado [28]), performance (R. Kangari, F. Farid, H. M. Elgharib [29]), stock return (T. Martikainen [30]; J.S. Abarbanell [31]; S. Kheradyar [32]) and profitability (M.N. Khan, I. Khokhar [33]) in companies.

The studies on financial ratios, at the same time, focus on measuring financial failure or bankruptcy. Studies use different models to predict the probability of financial failure or bankruptcy in the literature. For example, multiple regression [26], discriminant [26], logit [26]; [34], artificial neural network ([26]; H.C. Koh [24]; J. Chen [27]), logistic regression (H.C. Koh [24]; J. Chen [27]; M. Baş [1]; H. Li [35]; A.M.I. Lakshan [36]), decision tree (H.C. Koh [24]), grey relational analysis (M. Baş, Z. Çakmak [2]). 
In a significant part of other studies, Altman Z Score and Springate S-Score are preferred. For example J. Pindado [28], U. Büyükarıkan [37], İ. Kulali [38], M. Soba [39]), Z. Türk [40], O. Jawabreh [41], E. Dizgil [42], H. Bağc1 [43] used Z and S scores either together or by choosing one of them.

The common result of the studies using different methods is that each method used has a consistency within itself and they claim that the methods used in their studies predict financial success and failure correctly to a certain extent.

The studies given in the next part of the literature review focus directly on the relationship between financial distress or failure (especially in the context of Z-Score) and stock price.

Altman [21] stated that failure could be predicted two years before financial failure. E. I. Altman and M. Brenner [44] examined the effect of "new information" that expresses changes in the Altman Z-score, stock prices and found abnormal returns in their stock prices studies. I.D. Dichev [45], J.M. Griffin and M.L. Lemmon [46] and J.Y. Campbell [47] found a negative correlation between the probability of default in companies and stock returns means that firms with high bankruptcy risk earn lower than average returns by using the models suggested by E.I. Altman [21] and J.A. Ohlson [48]. However, M. Vassalou [49] found that in firms with smaller capital and smaller MV/BV ratio, default risk is priced in because it is reflected in the stock price, and stocks with high default risk have higher expected returns than those with low default risk.

In another study M.K. Çelik [50] tried to determine the relationship between the stock returns and financial failure in Turkey and did not find a significant relationship throughout the 1998-2008 period. $\mathrm{N}$. Apergis [51] also analyzed the stock price and bankruptcy according to the Altman Z-Score model and found a positive correlation between the Altman Z-Score and the company's stock price. This means that the stock prices of companies with low Z-Score are also low. Similar results were also found by I. B. Robu [52] in Romania, by E. Susilowati [53] in Indonesia and by G. Singh and R. Singla [54]. I. B. Robu et al. [52] found a difference between financially distressed companies and well-performing companies. The stock returns of companies in the high-risk category are lower than others. Simangunsong (2019) determined that the Z-score has a significant effect on stock prices. R. Singh and R. Singla [54] found that a positive relationship between Z-score and stock return. However, R. Afrin [55] did not find any relationship between Z-score and stock returns in the cement industry in Bangladesh.
Based on the findings of the studies given in this part of the study, we see that the Altman Z-Score model can substantially affect stock prices. Therefore Z-Score can be considered as an indicator for market performance and stock returns. Moreover, it is seen that the focus is on the Altman Z-Score, and the Springate S-Score is neglected in the literature. Therefore, the study also investigates long and short-term relationships between stock prices and the success grades obtained with the Springate S-Score and the Altman S-Score and fills the gap in the literature in this context.

\section{DATA AND METHODOLOGY}

The data set of the study were accessed from FINNET $^{5}$ (Financial Information News Network) database (finnet.com.tr/FinnetStore/En) and Borsa İstanbul Data Store (datastore.borsaistanbul.com). In this study, for Altman Z-Score analyses, 18 REITs and for Springate S-Score 17 REITs that traded in Borsa Istanbul between 2010: Q1 and 2019: Q4 and whose data can be fully accessed were considered. The REITs whose data were used in the study are shown in Appendix 1.

In the study, quarterly stock close prices of REITs were used as stock prices, and financial ratios were used to calculate Altman Z-Score and Springate S-Score. While calculating the Altman Z-Score, Z' model was used. This model was developed for companies except for the manufacturing sector [20].

In the study, panel co-integration tests were conducted to examine a long-term convergence among the relevant variables. Pedroni and Kao co-integration tests and the Panel ARDL Bound Test were used to examine the long-term relationship between the series. If there is evidence of co-integration based on any of the Pedroni and Kao co-integration tests, in that case, the long-term co-integration vector will be estimated with the group-mean panel DOLS (Dynamic Ordinary Least Square) and FMOLS (Fully Modified Ordinary Least Square) estimation techniques developed by P. Pedroni [56] and P. Pedroni [57]. The causality analysis based on Granger causality analysis developed by E.I. Dumitrescu and C. Hurlin [58] is used for causality tests.

The purpose of the panel co-integration test is to combine similar long-term information among various panel members [59]. P. Pedroni proposed seven cointegration tests for panel data based on co-integration residues of error terms. Three of them are considered group mean panel co-integration tests and are based

${ }^{5}$ FINNET (Financial Information News Network) (accessed on 12.02.2020). 


\section{Descriptive Statistics}

\begin{tabular}{|c|c|c|}
\hline Statistics & Price & z-Score \\
\hline Mean & 2.247158 & 43.82678 \\
\hline Median & 1.236309 & 4.717263 \\
\hline Maximum & 22.98000 & 1127.642 \\
\hline Minimum & 0.000000 & -3.489374 \\
\hline Std. Dev. & 2.945761 & 104.5659 \\
\hline Skewness & 3.210858 & 4.735053 \\
\hline Kurtosis & 14.87399 & 34.00045 \\
\hline Jarque-Bera & 5466.902 & 31521.33 \\
\hline Observations & 720 & 720 \\
\hline
\end{tabular}

Source: analysis output.

on between dimensions. They are created by dividing the numerator by the denominator before adding it over the $\mathrm{N}$-dimension. The other four, called panel co-integration tests, are based on dimensions and are formulated by adding both numerator and denominator above the $\mathrm{N}$ dimension [60]. Another of the panel cointegration tests is the C. Kao [61] test. In this test, the null hypothesis suggests no co-integration relationship between dependent and independent variables is tested. C. Kao [61] uses Dickey-Fuller and Augmented DickeyFuller (ADF) type test structures while examining the long-term relationship between the co-integration analysis panel series.

In the study, the relation between Springate S-Score and the stock price was also examined with Panel ARDL Boundary Test. M. Pesaran et al. [62] stated that ARDL model is based on three estimators: Mean Group Estimator (MG), Pooled Mean Group Estimator (PMG), and Dynamic Fixed Effects Estimator (DFE). The mean group estimator places no constraints on the ARDL model parameters. The most criticized aspect of the mean group estimator model is that the parameters between units in the panel are heterogeneous. On the other hand, in Pooled Group Estimator; Short-term parameters are allowed to be heterogeneous, while long-term parameters are allowed to be homogeneous between units. Finally, although the Dynamic Fixed Effects Estimator is similar to the pooled mean group estimator, it restricts the co-integration coefficient equally in all panels in the long run and allows intragroup correlation [63, 64].

Finally, in the study, we apply the panel Granger causality test for heterogeneous panels proposed by E.I. Dumitrescu and C. Hurlin [58]. The null hypothesis means no causal relationship between variables and is tested using an alternative z-bar statistic [65]. The models used in the study are as follows:

$$
\begin{aligned}
& \text { Price }_{i t}=\beta_{0 i}+\beta_{1 i} \text { zscore }_{i t}+\varepsilon_{i t}, \\
& \text { Price }_{i t}=\beta_{o i}+\beta_{1 i} \text { sscore }_{i t}+\varepsilon_{i t} .
\end{aligned}
$$

Where, Price $_{i t}$ is the stock prices in $i$ company at the time $t, z$ score $_{i t}$ and sscore $_{i t}$ are the financial failure scores as proxy financial failure in $i$ company at the time $t, \beta_{0}$ is a constant term, $\beta_{1}$ is slope coefficients of the model, $\varepsilon_{\mathrm{t}}$ is an error term.

\section{FINDINGS \\ Altman Z-Scores, Unit Root, Cointegration and Causality Results}

In the first stage of the analysis, Altman Z-Scores were calculated. Thus, we see in the table included in Appendix 2, Z-Scores. The green, orange, and red colours show success, grey zone, and failure status. Z-Scores are calculated quarterly between 2010 and 2019.

The calculated descriptive statistics are shown in (Table 1). Descriptive statistics show mean, median, maximum, and minimum values, standard deviation, skewness and kurtosis values, Jargue-Bera statistics, and the total number of observations for variables.

\section{Unit Root Test}

In the study, Fisher-Type ADF and PP tests (G. S. Maddala and S. Wu [66] and I. Choi [67], one of the panel unit root tests, were used to determine the stationarities of variables. The G.S. Maddala and $\mathrm{S}$. Wu [66] test offer a strategy that transcends the 
Unit Root Test Results

\begin{tabular}{|l|c|c|}
\hline \multicolumn{1}{|c|}{ Tests } & Price (Sta.) & Z-Score (Sta.) \\
\hline ADF - Fisher Chi-square & 51.5369 & 110.954 \\
& $(0.0450)$ & $(0.0000)$ \\
\hline PP - Fisher Chi-square & 73.2993 & 177.844 \\
& $(0.0002)$ & $(0.0000)$ \\
\hline Probabilities for Fisher-type tests are calculated using an asymptotic Chi-square distribution. The selection of lag levels for the \\
Fisher-ADF test was determined by the Schwarz Information Criteria. In calculations that used the Fisher PP test, Newey-West \\
automatic bandwidth selection, and Bartlett kernel. Contents in parentheses are probability values. Analyzes were carried out \\
according to fixed term models.
\end{tabular}

Source: analysis output.

limitations of both LLC and IPS tests. They propose a nonparametric test based on a combination of $p$ values of t-statistics for a unit root in each crosssectional unit (ADF test). This approach has the advantage of allowing as much heterogeneity between units as possible.

As a result of the analysis, it is seen that the null hypothesis claiming that both variables contain unit root in level values is rejected (Table 2).

\section{Pedroni and Kao Co-integration Analysis}

According to the Pedroni co-integration test results summarized in (Table 3), five of the seven statistics show co-integration, and two show no co-integration. Accordingly, the probability values of the Panel rho, Panel PP, Panel ADF statistics calculated as a result of the Pedroni co-integration test indicate a significant relationship at $1 \%$ and $5 \%$ significance levels. According to the Kao co-integration test result, the $H_{0}$ hypothesis, which suggests no cointegration between the series, is rejected at the $5 \%$ significance level. For this reason, it can be said that there is a co-integration relationship between the series. According to the results of the co-integration analysis, it can be said that the stock prices and ZScores series of REITs move together in the long run.

\section{Estimation of Cointegration Parameters by DOLS and FMOLS Methods}

After determining that the variables exhibit a longterm co-integration panel, the variables' long-run effects are estimated at the next stage. Considering that the OLS estimator is a biased and inconsistent estimator when applied to co-integrated panels, the long-term structural coefficients were estimated using DOLS developed by P. Pedroni [56] and FMOLS developed by P. Pedroni [57] procedures to generate consistent estimates.
According to P. Pedroni [56] DOLS method results in Table 4, where the dependent variable is Z-Score, the coefficient is estimated to be approximately 24.46. The estimated result is positive and statistically significant at the $1 \%$ significance level; It shows that the $1 \%$ change (increase) in stock prices across 18 REIT companies causes a change (increase) of approximately $24.46 \%$ on Z-Score in the long run. In the model where there is a dependent variable stock price, the coefficient is estimated as approximately 0.0036 . The estimated result is positive and statistically significant at the $1 \%$ significance level. It shows that the $1 \%$ change (increase) in the z scores across 18 companies causes a change (increase) of approximately $0.0036 \%$ in the long run on foreign direct portfolio investments. These results show that the change in stock prices is more effective on their Z-Scores.

Another method suggested by P. Pedroni [57] is the FMOLS method. Similar results were obtained in this method. If the dependent variable is the Z-Score, the coefficient is calculated to be approximately 16.26 . Since the results summarized in (Table 4 ) are positive and statistically significant at the $1 \%$ significance level, the $1 \%$ change in stock prices causes a change of $16.26 \%$ on the Z-Score in the long run. In the model where there is a dependent variable stock price, the coefficient is estimated at approximately 0.0025 . The estimated result is positive and statistically significant at the $1 \%$ significance level; It shows that the $1 \%$ change (increase) in the Z-Score across 18 REIT companies causes a change (increase) of approximately $0.0025 \%$ in the long run on stock prices. The results obtained with the FMOLS method also show that stock price changes are more effective on Z scores, as in the DOLS method. The fact that the coefficients obtained as a result of both DOLS and FMOLS methods are positive indicates a positive relationship between the series in the long term. 


\section{Co-integration results}

\begin{tabular}{|c|c|c|c|c|}
\hline \multicolumn{5}{|c|}{ Pedroni } \\
\hline Within-dimension (Panel) & Statistic & Prob. & Within-Weighed & Prob. \\
\hline Panel v-Statistic & 0.759129 & 0.2239 & -2.553410 & 0.9947 \\
\hline Panel rho-Statistic & -4.946637 & $0.0000^{*}$ & -9.039565 & $0.0000^{*}$ \\
\hline Panel PP-Statistic & -4.776949 & $0.0000^{*}$ & -10.12467 & $0.0000^{*}$ \\
\hline Panel ADF-Statistic & -2.609403 & $0.0045^{*}$ & -5.700882 & $0.0000^{*}$ \\
\hline Between- dimension (Group) & Statistic & Prob. & & \\
\hline Group rho-Statistic & -3.537513 & $0.0002^{*}$ & & \\
\hline Group PP-Statistic & -4.679810 & $0.0000^{*}$ & & \\
\hline Group ADF-Statistic & -1.607361 & $0.0540^{* * *}$ & & \\
\hline \multicolumn{5}{|c|}{ Kao } \\
\hline \multirow{2}{*}{\multicolumn{3}{|c|}{ ADF }} & t-Statistic & Prob. \\
\hline & & & 1.901743 & $0.0286^{* *}$ \\
\hline \multicolumn{3}{|l|}{ Residual variance } & 0.609277 & \\
\hline \multicolumn{3}{|l|}{ HAC variance } & 0.454198 & \\
\hline \multicolumn{5}{|c|}{$\begin{array}{l}\text { The null hypothesis is that the variables are not co-integrated. Under the null hypothesis, all statistics are distributed as } \\
\text { standard normal distributions. The finite sample distribution of seven statistics is tabulated in Pedroni (2004). Barlett Kerneli } \\
\text { and Newey-West bandwidth criteria were used in both tests used to determine the co-integration relationship. SIC criterion was } \\
\text { used in calculating the optimum lag lengths for the variables. The }{ }^{* *}, \text {, and }{ }^{* * *} \text { signs indicate that the relevant statistical values } \\
\text { are significant at the 1\%, 5\%, and 10\% significance levels, respectively. Trend assumption is determined as the deterministic trend } \\
\text { and constant. }\end{array}$} \\
\hline
\end{tabular}

Source: analysis output.

\section{Dumitrescu and Hurlin Panel Causality}

DH Panel Causality test developed by E. I. Dumitrescu and C. Hurlin [58] and considers the possible crosssectional dependence between the horizontal sections that make up the panel. This test, which is insensitive to the size difference between time and section size, can yield effective results in both cases [68]. Table 5 shows E. I. Dumitrescu and C. Hurlin Panel causality test results. According to the analysis results, since the probability values are lower than the $5 \%$ significance level, there is bidirectional causality between variables. (Table 5) also gives detailed information about the causality relationship between variables. Due to the probability values being less than 0.05 , the null hypotheses that " $Z$ Score does not homogeneously cause Price" and "Price does not homogeneously cause Z-Score" can be rejected. This means that there is a significant conclusion that $Z$-Score influences stock prices and vice versa.

\section{Springate S-Score, Unit Root, Long and Short-Term Relations}

Springate S-Scores were calculated quarterly between 2010-2019 in the next stage of the study. S-Scores are shown in the table in Appendix 3. Data from 17 REIT companies that were continuously traded in Borsa Istanbul between 2010 and 2019 were used in the study.

The descriptive statistics of variables are shown in Table 6. In (Table 6), mean, median, maximum, and minimum values, standard deviation, skewness and kurtosis values, Jargue-Bera statistics, and total observations are seen.

\section{Unit Root Tests}

In this part of the study, where the relationship between Springate S-Score and the stock price was investigated, Fisher-Type ADF and PP tests were used again for unit root tests. As a result of the analysis, in (Table 7), the null hypothesis that the S-Score 
DOLS and FMOLS Results

\begin{tabular}{|c|c|c|c|c|}
\hline Method & Variable & Coefficient & Std. Error & t-Statistic \\
\hline \multirow{2}{*}{ DOLS } & $\begin{array}{l}\text { Dependent: Z-Score, } \\
\text { Independent: Price }\end{array}$ & $\begin{array}{c}24.46178 \\
(0.0001)\end{array}$ & 6.053025 & 4. 041250 \\
\hline & $\begin{array}{l}\text { Dependent: Price, } \\
\text { Independent: Z-Score }\end{array}$ & $\begin{array}{c}0.003585 \\
(0.0001)\end{array}$ & 0.000921 & 3. 893583 \\
\hline \multirow{2}{*}{ FMOLS } & $\begin{array}{l}\text { Dependent: Z-Score, } \\
\text { Independent: Price }\end{array}$ & $\begin{array}{l}16.26137 \\
(0.0002)\end{array}$ & 4.347447 & 3. 740442 \\
\hline & $\begin{array}{l}\text { Dependent: Price, } \\
\text { Independent: Z-Score }\end{array}$ & $\begin{array}{c}0.002521 \\
(0.0003)\end{array}$ & 0.000688 & 3.666585 \\
\hline
\end{tabular}

Source: analysis output.

Table 5

\section{Dumitrescu-Hurlin Panel Causality Test Results}

\begin{tabular}{|l|c|c|c|}
\hline \multicolumn{1}{|c|}{ Null } & W-Stat. & Zbar-Stat. & Prob. \\
\hline Z-Score does not homogeneously cause Price & 8.63114 & 12.1465 & 0.0000 \\
\hline Price does not homogeneously cause Z-Score & 3.40894 & 2.39098 & 0.0168 \\
\hline
\end{tabular}

Source: analysis output.

Descriptive Statistics

\begin{tabular}{|c|c|c|}
\hline Statistics & Price & S-Score \\
\hline Mean & 2.309971 & 36.63462 \\
\hline Median & 1.250000 & 26.95921 \\
\hline Maximum & 22.98000 & 109.8168 \\
\hline Minimum & 0.260000 & 0.779670 \\
\hline Std. Dev. & 3.009476 & 30.11446 \\
\hline Skewness & 3.135836 & 0.818395 \\
\hline Kurtosis & 14.22471 & 2.517112 \\
\hline Jarque-Bera & 4670.513 & 82.27134 \\
\hline Observations & 680 & 680 \\
\hline
\end{tabular}

Source: analysis output.

variable in the first difference contains the unit root in the level values of the share price variable is rejected.

\section{Panel ARDL Bound Test Results}

2The ARDL bound test approach introduced by M. Pesaran et al. [69] was used to investigate the relationship between the level of financial success and stock price in real estate investment trust companies. The ARDL co-integration approach has many advantages compared to other co-integration methods such as R. Engle and C. Granger [70], S. Johansen [71], and S. Johansen and K. Juselius [72]. First, the ARDL procedure can be applied regardless of whether the series is $I(0)$ or $I(1)$. This means that the ARDL procedure has the advantage of avoiding the classification of variables as $I(0)$ or $I(1)$ and that unit root pretesting is not required. Second, the validity of the Johansen co-integration techniques requires large 
Unit Root Tests

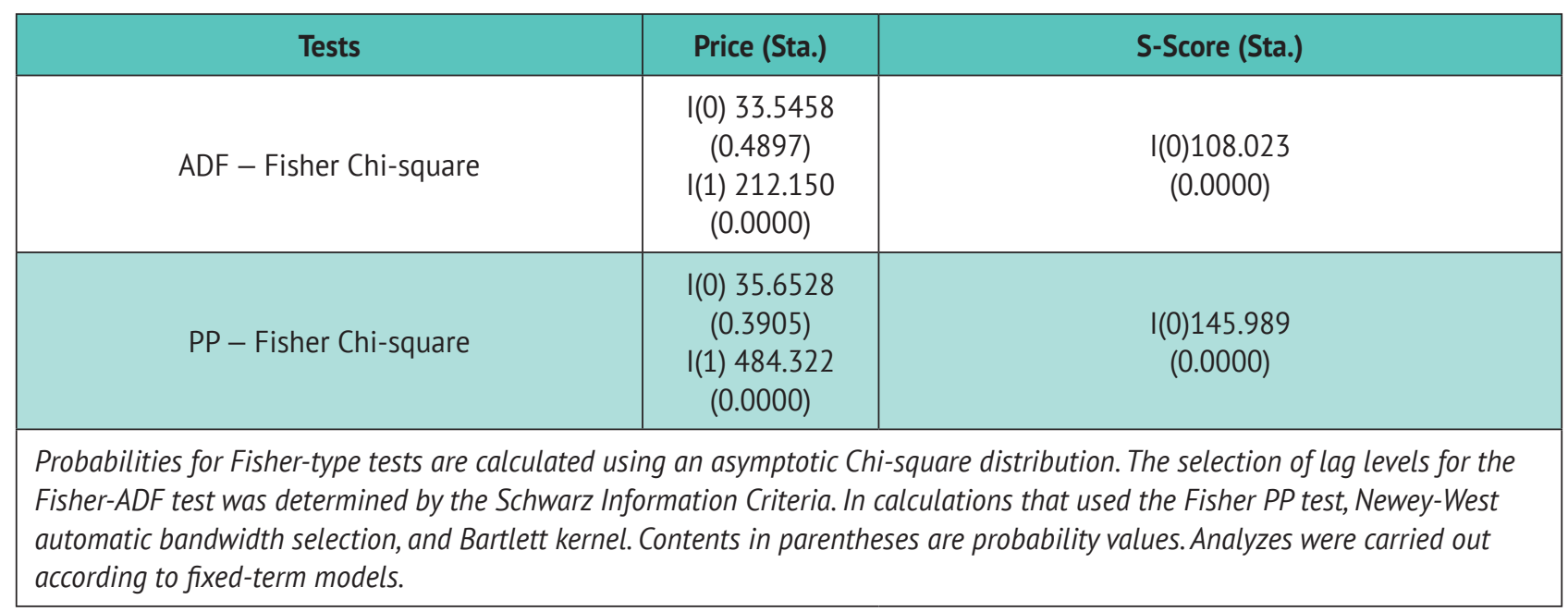

Source: analysis output.

\section{Bound Test Results}

\begin{tabular}{|c|c|c|c|c|c|}
\hline & & \multicolumn{2}{|c|}{$\mathbf{1 \%}$ Critical Values } & \multicolumn{2}{|c|}{ 5\% Critical Values } \\
\hline $\mathrm{k}^{*}$ & F-statistic & $\begin{array}{l}\text { Lower } \\
\text { Bound }\end{array}$ & Upper Bound & Lower Bound & $\begin{array}{c}\text { Upper } \\
\text { Bound }\end{array}$ \\
\hline 1 & 6.350150 & 4.94 & 5.58 & 3.62 & 4.16 \\
\hline${ }^{*} k$ represents the number of independent variables. Critical values were obtained from the study made by Pesaran et al. (2001). \\
\hline
\end{tabular}

Source: analysis output.

data samples. At the same time, the ARDL procedure is a more statistically effective approach used in small samples to determine the co-integration relationship. Third, the ARDL procedure allows variables to have different optimal delays. Finally, while the ARDL procedure uses a single reduced form equation, they predict long-term relationships in the context of system equations in traditional co-integration procedures $[73,74]$.

In this study, since the Springate S-Score and stock price variables are stable at different levels, the advantages offered by the Panel ARDL method were used in the analysis. The ARDL boundary test approach is based on the least-squares estimator's estimation and the unbounded error correction model.

In the study, the co-integration relationship between variables was first tested with the help of the bounds test approach. Table 8 shows the results of the margin test analysis. Critical values are valid for the independent variable and the $1 \%$ and $5 \%$ significance levels. Since the calculated F statistic is above the upper critical levels, it is possible to say a co-integration relationship between variables. In other words, share prices and s-scores are integrated. That is, they act together in the long run. In this context, it can be said that any change in s-scores will have effects on share prices. Therefore, it was decided that the ARDL model can be used to determine the long and short-term dynamics between variables.

In order to estimate the long-term relationship between variables, the optimum lag length has been determined as one, and in this context, ARDL $(1,1)$ model is the most suitable. Table 9 shows the results of the long-term dynamics between the share price and the S-Score. Lag lengths were determined by taking into account the values of Schwarz information criteria. The long-term dynamics results indicate a positive and significant relationship between share price and S-Score. Accordingly, a one-unit increase in the S-Score increases the share price by approximately 0.06 units in the long run. However, looking at the short-term dynamics, it is seen that there is no relationship.

In the next step, the analysis was repeated for the case where the dependent variable was the S-Score. 
Results of ARDL $(1,1)$ (Dependent Variable: Stock Price)

\begin{tabular}{|c|c|c|c|c|}
\hline Variable & Coefficient & Std. Error & t-Statistic & Prob. $^{*}$ \\
\hline & \multicolumn{2}{|c|}{ Long Run Equation } & & \\
\hline S-Score & 0.058265 & 0.019276 & 3.022718 & 0.0026 \\
\hline COINTEQ01 & \multicolumn{2}{|c|}{ Short Run Equation } & & \\
\hline D(S-Score) & -0.130080 & 0.039846 & -3.264593 & 0.0012 \\
\hline C & -0.006103 & 0.003810 & -1.601802 & 0.1097 \\
\hline
\end{tabular}

Source: analysis output.

\section{Bound Testing Results}

\begin{tabular}{|c|l|l|l|l|l|}
\hline & & \multicolumn{2}{|c|}{ 1\% Critical Values } & \multicolumn{2}{c|}{ 5\% Critical Values } \\
\hline $\mathrm{k}^{*}$ & F-statistic & Lower Bound & Upper Bound & Lower Bound & Upper Bound \\
\hline 1 & 21.07600 & 4.94 & 5.58 & 3.62 & 4.16 \\
\hline${ }^{*} k$ represents the number of independent variables. Critical values were obtained from the study made by Pesaran et al. (2001). \\
\hline
\end{tabular}

Source: analysis output.

Results of ARDL $(1,1)$ (Dependent Variable: S-Score)

\begin{tabular}{|c|c|c|c|c|}
\hline Variable & Coefficient & Std. Error & t-Statistic & Prob.* \\
\hline & \multicolumn{2}{|c|}{ Long Run Equation } & & \\
\hline \multirow[t]{2}{*}{ Price } & -1.082561 & 0.383779 & -2.820790 & 0.0049 \\
\hline & \multicolumn{2}{|c|}{ Short Run Equation } & & \\
\hline Cointeq01 & -0.407846 & 0.040539 & -10.06063 & 0.0000 \\
\hline $\mathrm{D}$ (Price) & -0.650049 & 3.730520 & -0.174252 & 0.8617 \\
\hline C & 2.261466 & 0.962972 & 2.348423 & 0.0192 \\
\hline
\end{tabular}

Source: analysis output.

The co-integration relationship between variables was tested with the help of the boundary test approach. (Table 10) shows the results of the bound test analysis. Since the calculated F statistic is above the upper critical levels, it is possible to say a co-integration relationship between variables. So, stock prices and $\mathrm{S}$-Scores are integrated. That is, they act together in the long run. In this context, it can be said that any change in stock prices will have effects on S-Scores. Therefore, it was decided that the ARDL model can be used to determine the long and short-term dynamics between variables.
In order to estimate the long-term relationship between variables, the optimum lag length has been determined as one. In this context, ARDL $(1,1)$ model is the most suitable. (Table 11) shows the results of the long-run dynamics between the stock price and the S-Score. The lag lengths were determined by taking into account the values of Schwarz information criteria. The long-term dynamics results indicate a negative and significant relationship between the $\mathrm{S}$-Score and the stock price. Accordingly, a one-unit increase in the stock price decreases the S-Score by approximately -1.08 units in the long run. However, 
Dumitrescu-Hurlin Panel Causality Test Results

\begin{tabular}{|c|l|l|l|}
\hline Null Hypothesis: & \multicolumn{1}{|c|}{ W-Stat. } & \multicolumn{1}{|c|}{ Zbar-Stat. } & \multicolumn{1}{c|}{ Prob. } \\
\hline S-Score does not homogeneously cause Price & 3.26328 & 2.05820 & 0.0396 \\
\hline Price does not homogeneously cause S-Score & 2.65511 & 0.95437 & 0.3399 \\
\hline
\end{tabular}

Source: analysis output.

looking at the short-term dynamics, it is seen that there is no relationship.

Table 12 shows Dumitrescu and Hurlin Panel causality test results. Unlike the Altman Z-Score and stock price relationship, a one-way causality has been identified. According to (Table 12), since the probability values are lower than the $5 \%$ significance level, there is a one-way causality between variables. The direction of causality is from the S-Score to the stock price. Due to the probability values being less than 0.05 , the null hypothesis that "S-Score does not homogeneously cause Price" can be rejected but "Price does not homogeneously cause Z-Score" null hypotheses can not be rejected. This means that there is a significant conclusion that $S$-Score influences stock prices but not true vice versa.

\section{CONCLUSION AND DISCUSSION}

Companies that do not pay attention to their financial performance may face the risk of financial failure or bankruptcy. As we see in the literature, companies' financial failure or bankruptcy risk can be measured using Altman Z-Score and Springate $S$-Score models frequently. However, the number of studies investigating the relationship between financial failure and stock performance is relatively limited in the literature. Therefore, in this study, the relationships between financial failure or bankruptcy predictions and stock prices were investigated to fill this gap.

Investors want to get the highest return by choosing the financial investment tools that are most suitable for them. Stocks have a significant place among financial investment instruments today. Investors are looking for ways to earn higher returns from stock investments, as is the case with all financial investment instruments. In this direction, investors try to achieve higher investment performance by considering the various characteristics of the companies and the stocks belonging to the companies in question.

In this study, the relationship between financial failure or bankruptcy risk score and stock price was investigated in companies operating in the REITs traded on Borsa Istanbul in Turkey. The results show that $\mathrm{Z}$ and $\mathrm{S}$ scores, which are considered indicators of bankruptcy or financial failure, affect stock prices positively and significantly in the long run. When the bankruptcy indicator improves, stock prices follow an upward trend. The causality relationships show a double-sided causality between the Z-Score and stock prices and a one-sided between the S-Score and stock prices. In addition, there is causality from S-Scores to stock prices. Empirical findings show that investors consider information about the economic and financial conditions of the companies they invest in.

The obtained results in this study are in harmony with the studies such as I.D. Dichev [45], J.D. Piotroski [75], J.M. Griffin and M.L. Lemmon [46], N. Apergis [51], I. B. Robu [52], E. Susilowati [53], G. Singh and R. Singla [54].

It has been suggested in the literature that companies with high levels of financial distress (low $\mathrm{Z}$ and $\mathrm{S}$ scores) have a higher risk of investing in stocks. Investing in stocks of companies with scores below certain levels is riskier, as low Altman Z-Score and Springate S-Score are indicators of financial distress and bankruptcy risk. This situation reduces stock prices and returns [75]. However, in some of the studies in the literature, it is emphasized that higher risk in any investment brings together higher expected return. At the same time, scores from bankruptcy models are related to the company's market value and systematic risk. Therefore, N. Apergis et al. [51] stated that companies with high scores in terms of bankruptcy risk should be expected to provide more returns to shareholders to compensate for the high risk. However, the number of studies supporting these cases is quite limited.

The study results are important in revealing essential conclusions for both REITs and the investors of REITs. It is vital for sector representatives whether the stock prices are related to the financial failure probability of REITs and to what extent. This study can be developed by considering different sectors, focusing on developed and developing financial markets, and using different econometric methods with financial failure prediction models other than Altman Z-Score and Springate S-Score models. 


\section{REFERENCES}

1. Al Saedi A., Al Timimi S.A. The relationship between financial failure and market value: An empirical study using a sample of industrial firms listed at Qatar Stock Exchange. Academy of Accounting and Financial Studies Journal. 2018;22(5). URL: https://www.abacademies.org/articles/The-Relationship-Between-FinancialFailure-and-Market-Value-1528-2635-22-5-287.pdf

2. Baş M., Çakmak Z. Gri ilişkisel analiz ve lojistik regresyon analizi ile işletmelerde finansal başarısızlığın belirlenmesi ve bir uygulama. Anadolu Üniversitesi Sosyal Bilimler Dergisi. 2012;12(3):63-82. URL: https://www. researchgate.net/publication/329881822_Gri_iliskisel_analiz_ve_lojistik_regresyon_analizi_ile_isletmelerde_ finansal_basarisizligin_belirlenmesi_ve_bir_uygulama

3. Du Jardin P. Bankruptcy prediction models: How to choose the most relevant variables? Bankers, Markets and Investor. 2009;(98):39-46. URL: https://www.researchgate.net/publication/235643766_Bankruptcy_prediction_ models_How_to_choose_the_most_relevant_variables

4. Yakut E., Elmas B. İşletmelerin finansal başarısızlığının veri madenciliği ve diskriminant analizi modelleri ile tahmin edilmesi. Afyon Kocatepe Üniversitesi İIBF Dergisi. 2013;15(1):261-280. URL: https://dergipark.org.tr/ tr/download/article-file/18872

5. Selimoğlu S., Orhan A. Finansal başarısızlığın oran analizi ve diskriminant analizi kullanılarak ölçümlenmesi: BIST’de işlem gören dokuma, giyim eşyası ve deri işletmeleri üzerine bir araştırma. Muhasebe ve Finansman Dergisi = The Journal of Accounting and Finance. 2015;(66):21-40. DOI: 10.25095/ mufad.396529

6. Shen J. Distress risk and stock returns on equity REITs. The Journal of Real Estate Finance and Economics. 2021;62(8):455-480. DOI: 10.1007/s11146-020-09756-7

7. Hayta Ö. Gayrimenkul yatırım ortaklıkları ve gayrimenkul yatırım ortaklıkları performans değerlendirmesi: IMKB’de bir uygulama. Yayınlanmamış Yüksek Lisans Tezi. Adana: Çukurova Üniversitesi, Sosyal Bilimleri Enstitüsü. 2009.

8. Çelik Ş., Manan M.T. Gayrimenkul yatırım ortaklıklarinin risk ile performans ilişkisi. Muhasebe ve Finans İncelemeleri Dergisi. 2018;1(1):60-79. DOI: 10.32951/mufider.385054

9. Chung R., Fung S., Shilling J.D., Simmons-Mosley T.X. REIT stock market volatility and expected returns. Real Estate Economics. 2016;44(4):968-995. DOI: 10.1111/1540-6229.12128

10. Sert K., Biçer A.A. Gayrimenkul yatırım ortaklıklarının kilit denetim konularıyla ilişkisi. Working Paper Series. 2021;2(1):1-13. URL: http://acikerisim.ticaret.edu.tr/xmlui/bitstream/handle/11467/4794/22-Makale\%20 Metni-240-1-10-20210322.pdf?sequence=1 \&isAllowed=y

11. Apan M. Gayrimenkul yatırım ortaklıklarının piyasa yapısı ve yoğunlaşma düzeylerinin analizi: Borsa İstanbul'dan kanttlar. Celal Bayar Üniversitesi Sosyal Bilimler Dergisi. 2020;18:235-250. DOI: 10.18026/ cbayarsos. 596856

12. Ayrancı A.E., Gürel C.A. Gayrimenkul yatırım ortaklıklarının finansal performansı: BİST işletmeleri örneği. International Journal of Applied Economic and Finance Studies. 2020;5(1). URL: http://www.ijaefs.com/wpcontent/uploads/2020/05/01_ERTUGRUL-AYRANCIL-GUREL.pdf

13. Aktaş R. Mali başarısızlık (işletme riski) tahmin modelleri. Ankara: Türkiye İş Bankası Kültür Yayınları, Genel Yayın. 1997;(323).

14. Beaver W.H. Financial ratios as predictors of failure. Journal of Accounting Research. 1966;4:71-111. DOI: $10.2307 / 2490171$

15. Altman E.I., Hotchkiss E. Corporate financial distress and bankruptcy: Predict and avoid bankruptcy, analyze and invest in distressed debt. Hoboken, NJ: John Wiley \& Sons, Inc.; 2006. 368 p.

16. Özdemir F.S., Choi F.D.S., Bayazıtlı E. Finansal başarısızlık tahminleri yönüyle UFRS ve bilginin ihtiyaca uygunluğu. Mali Çözüm. 2012;22(112):17-52. URL: https://docplayer.biz.tr/8686317-Finansal-basarisizliktahminleri-yonuyle-ufrs-ve-bilginin-ihtiyaca-uygunlugu.html

17. Akkaya G.C., Demireli E., Yakut Ü.H. İşletmelerde Finansal Başarısızlık Tahminlemesi: Yapay Sinir Ağları Modeli İle İMKB Üzerine Bir Uygulama. Eskişehir Osmangazi Üniversitesi Sosyal Bilimler Dergisi. 2009;10(2):187-216.

18. Tükenmez N.M., Demireli E., Akkaya G.C. Finansal başarısızlığın tahminlenmesinde diskriminant analizi, lojistik regresyon ve Chaid karar ağacı modellerinin karşılaştırılması: KOBİ'ler üzerine bir uygulama. 16. Finans Sempozyumu (Erzurum, 10-13 Ekim. 2012). Erzurum: Atatürk Üniversitesiİktisadi ve İdari Bilimler Fakültesi; 2012. 
19. Aksoy E.E.A., Göker İ.E.K. Bankacılık sektöründe finansal risklerin Z-Skor ve Bankometer Metodları ile tespiti, BİST’te İșlem Gören Ticari Bankalar Üzerine Bir Araştırma. Muhasebe Bilim Dünyası Dergisi. 2018;20(2):418-438. DOI: $10.31460 /$ mbdd. 377424

20. Ko Y.C., Fujita H., Li T. An evidential analysis of Altman Z-score for financial predictions: Case study on solar energy companies. Applied Soft Computing. 2017;52:748-759. DOI: 10.1016/j.asoc.2016.09.050.

21. Altman E.I. Financial ratios, discriminant analysis and the prediction of corporate bankruptcy. The Journal of Finance. 1968;23(4):589-609. DOI: 10.1111/j.1540-6261.1968.tb00843.x

22. Nedzveckas J., Jurkevičius E., Rasimavičius G. Testing of bankruptcy prediction methodologies for Lithuanian market. Mokslo Taikomieji Tyrimai Lietuvos Kolegijose. 2003;3(1):54-64.

23. Springate G.L.V. Predicting the possibility of failure in a Canadian firm: A discriminant analysis. Theses. Burnaby, BC: Simon Fraser University; 1978. 164 p.

24. Koh C.H., Low K.C. Going concern prediction using data mining techniques. Managerial Auditing Journal. 2004;19(3):462-476. DOI: 10.1108/02686900410524436

25. Ege İ., Bayrakdaroğlu A. İMKB şirketlerinin hisse senedi getiri başarılarının lojistik regresyon tekniği ile analizi. ZKÜ Sosyal Bilimler Dergisi. 2009;5(10):139-158. URL: https://www.acarindex.com/dosyalar/makale/ acarindex-1423937120.pdf

26. Aktaş R., Doğanay M., Yıldız B. Finansal başarısızlığın öngörülmesi: İstatistiksel yöntemler ve yapay sinir ağı karşılaştırması. Ankara Üniversitesi SBF Dergisi. 2003;58(4):1-24.

27. Chen J., Marshall B.R., Zhang J., Ganesh S. Financial distress prediction in China. Review of Pacific Basin Financial Markets and Policies. 2006;9(2):317-336. DOI: 10.1142/S 0219091506000744

28. Pindado J., Rodrigues L., de la Torre C. Estimating financial distress likelihood. Journal of Business Research. 2008;61(9):995-1003. DOI: 10.1016/j.jbusres.2007.10.006

29. Kangari R., Farid F., Elgharib H.M. Financial performance analysis for construction industry. Journal of Construction Engineering and Management. 1992;118(2):349-361. DOI: 10.1061/(ASCE)0733-9364(1992)118:2(349)

30. Martikainen T. Stock returns and classification pattern of firm-specific financial variables: Empirical evidence with Finnish data. Journal of Business Finance \& Accounting. 1993;20(4):537-557. DOI: 10.1111/j.1468-5957.1993. tb00273.x

31. Abarbanell J. S., Bushee B. J. Abnormal returns to a fundamental analysis strategy. The Accounting Review. 1998;73(1):19-45.

32. Kheradyar S., Ibrahim I., Nor F.M. Stock return predictability with financial ratios. International Journal of Trade, Economics and Finance. 2011;2(5):391-396. DOI: 10.7763/IJTEF.2011.V2.137

33. Khan M.N., Khokhar I. The effect of selected financial ratios on profitability: an empirical analysis of listed firms of cement sector in Saudi Arabia. Quarterly Journal of Econometrics Research. 2015;1(1):1-12. DOI: 10.18488/ journal.88/2015.1.1/88.1.1.12

34. Voiko A.V. Bankruptcy prediction models for construction companies in the Russian Federation. Finansy: teoriya i praktika = Finance: Theory and Practice. 2019;23(5):62-74. DOI: 10.26794/2587-5671-2019-23-5-62-74

35. Li H., Sun J. Forecasting business failure: The use of nearest-neighbour support vectors and correcting imbalanced samples - evidence from the Chinese hotel industry. Tourism Management. 2012;33(3):622-634. DOI: 10.1016/j.tourman.2011.07.004

36. Lakshan A.M.I., Wijekoon W.M.H.N. The use of financial ratios in predicting corporate failure in Sri Lanka. GSTF Journal on Business Review (GBR). 2013;2(4):37-43. DOI: 10.5176/2010-4804_2.4.249

37. Büyükarıkan U., Büyükarıkan B. Bilişim sektöründe faaliyet gösteren firmaların finansal başarısızlık tahmin modelleriyle incelenmesi. Akademik Bakış Dergisi. 2014;46:160-172. URL: https://dergipark.org.tr/tr/download/ article-file/382916

38. Kulalı İ. Altman Z-Skor modelinin BİST şirketlerinin finansal başarısızlık riskinin tahmin edilmesinde uygulanması. Uluslararası Yönetim İktisat ve İsletme Dergisi = International Journal of Management Economics and Business. 2016;12(27):283-292. DOI: 10.17130/ijmeb.2016.12.27.1076

39. Soba M., Akyüz F., Uğurcan Y. Şirketlerin finansal performanslarının Altman yöntemiyle analizi: Borsa İstanbul örneği. Ușak Üniversitesi Sosyal Bilimler Dergisi. 2016;9(28/4):65-87. URL: https://dergipark.org.tr/tr/download/ article-file/603209

40. Türk Z., Kürklü E. Financial failure estimate in BIST companies with Altman (Z-Score) and Springate (S-Score) models. Osmaniye Korkut Ata Üniversitesi İktisadi ve İdari Bilimler Fakültesi Dergisi = Journal of Economics and Administrative Sciences. 2017;1(1):1-14. URL: https://dergipark.org.tr/tr/download/article-file/319546 
41. Jawabreh O., Al Rawashdeh F., Alsinglawi O. Using Altman's Z-Score model to predict the financial failure of hospitality companies - Case of Jordan. International Journal of Information, Business and Management. 2017;9(2):141-157.

42. Dizgil E. BIST Ticaret Endeksinde yer alan şirketlerin Springate finansal başarısızlık modeli ile incelenmesi. Bilecik Şeyh Edebali Üniversitesi Sosyal Bilimler Enstitüsü Dergisi. 2018;3(2):248-267. DOI: 10.33905/ bseusbed.462059

43. Bağcı H., Sağlam Ş. Sağlık ve spor kuruluşlarında finansal başarısızlık tahmini: Altman, Springate ve Fulmer modeli uygulaması. Hacettepe Sağllk İdaresi Dergisi. 2020;23(1):149-164. URL: https://dergipark.org.tr/en/ download/article-file/1013954

44. Altman E.I., Brenner M. Information effects and stock market response to signs of firm deterioration. Journal of Financial and Quantitative Analysis. 1981;16(1):35-51. DOI: 10.2307/2330665

45. Dichev I.D. Is the risk of bankruptcy a systematic risk? The Journal of Finance. 1998;53(3):1131-1147. DOI: 10.1111/0022-1082.00046

46. Griffin J.M., Lemmon M.L. Book-to-market equity, distress risk, and stock returns. The Journal of Finance. 2002;57(5):2317-2336. DOI: 10.1111/1540-6261.00497

47. Campbell J.Y., Hilscher J., Szilagyi J. In search of distress risk. The Journal of Finance. 2008;63(6):2899-2939. DOI: $10.1111 / \mathrm{j} .1540-6261.2008 .01416 . x$

48. Ohlson J.A. Financial ratios and the probabilistic prediction of bankruptcy. Journal of Accounting Research. 1980;18(1):109-131. DOI: 10.2307/2490395

49. Vassalou M., Xing Y. Default risk in equity returns. The Journal of Finance. 2004;59(2):831-868.

50. Çelik M.K. Finansal Olarak Başarili Ve Başarisiz Firmalarin Borsa Performanslarinin Karşilaştirilmasi: IMKB Örneği. Karadeniz Teknik Üniversitesi Sosyal Bilimler Dergisi. 2011;(2)7-16. URL: https://dergipark.org.tr/tr/ download/article-file/193279

51. Apergis N., Sorros J., Artikis P., Zisis V. Bankruptcy probability and stock prices: The effect of Altman Z-score information on stock prices through panel data. Journal of Modern Accounting and Auditing. 2011;7(7):689696.

52. Robu I.B., Robu M.-A., Mironiuc M., Bălu F. O. The value relevance of financial distress risk in the case of RASDAQ companies. Accounting and Management Information Systems. 2014;13(4):623-642.

53. Susilowati E., Simangunson J.M. Financial distress, bankruptcy analysis and implications for stock prices of consumer goods companies in Indonesia. Relevance: Journal of Management and Business. 2019;2(2):227-240. DOI: $10.22515 /$ relevance.v2i2.1862

54. Singh G., Singla R. Default risk and stock returns: Evidence from Indian corporate sector. Vision: The Journal of Business Perspective. 2021. DOI: 10.1177/09722629211003358

55. Afrin R. Analysing the potential of Altman's Z-score for prediction of market performance and share returns A case study of the cement industry in Bangladesh. The AUST Journal of Science and Technology. 2014;6(12):1-16. URL: https://www.aust.edu/storage/files/6okpiTQCsW8M7SSVpVk6WsZZ9i0zdYqzDWA4ApOp.pdf

56. Pedroni P. Purchasing power parity tests in co-integrated panels. The Review of Economics and Statistics. 2001;83(4):727-731. DOI: 10.1162/003465301753237803

57. Pedroni P. Fully-modified OLS for heterogeneous cointegrated panels. In: Baltagi B.H., Fomby T. B.. Carter Hill R., eds. Nonstationary panels, panel cointegration, and dynamic panels. Bingley: Emerald Group Publishing Ltd; 2001:93-130. (Advances in Econometrics. Vol. 15). DOI: 10.1016/S 0731-9053(00)15004-2

58. Dumitrescu E.-I.; Hurlin C. Testing for Granger non-causality in heterogeneous panels. Economic Modelling. 2012;29(4):1450-1460. DOI: 10.1016/j.econmod.2012.02.014

59. Law S.H., Azman-Saini W.N.W, Tan H.B. Economic globalization and financial development in East Asia: A panel cointegration and causality analysis. Emerging Markets Finance and Trade. 2014;50(1):210-225. DOI: 10.2753/ree1540-496x500112

60. Rehman F.U., Noman A.A., Ding Y. Does infrastructure increase exports and reduce trade deficit? Evidence from selected South Asian countries using a new Global Infrastructure Index. Journal of Economic Structures. 2020;9(1):10. DOI: 10.1186/s40008-020-0183-X

61. Kao C., Chiang M.H. On the estimation and Inference of a co-integrated regression in panel data. In: Baltagi B.H., Fomby T.B.. Carter Hill R., eds. Nonstationary panels, panel cointegration, and dynamic panels. Bingley: Emerald Group Publishing Ltd; 2001:179-222. (Advances in Econometrics. Vol. 15). DOI: 10.1016/S 0731-9053(00)15007-8 
62. Pesaran M.H., Shin Y., Smith R.P. Pooled mean group estimation of dynamic heterogeneous panels. Journal of the American Statistical Association. 1999;94(446):621-634. DOI: 10.2307/2670182

63. Rafindadi A., Yosuf Z. An application of panel Ardl in analyzing the dynamics of financial development and economic growth in 38 Sub-Saharan African continents. In: Kuala Lumpur International Business, Economics and Law Conference (Kuala Lumpur, Dec. 2-3, 2013). 2013:118-135. URL: https://www.researchgate. net/publication/274084627_An_Application_of_panel_ARDL_in_analysing_the_dynamics_of_financial_ development_and_economic_growth_in_38_Sub-Saharan_African_continents

64. Çadırcı B.D., Güner B. Türkiye’de iller bazında sektörel elektrik tüketimi ve ekonomik büyüme ilişkisi: Panel Ardl sınır testi yaklaşımı. Mehmet Akif Ersoy Üniversitesi Sosyal Bilimler Enstitüsü Dergisi. 2020;(31):41-60. DOI: 10.20875/makusobed.596894

65. Isaeva A., Salahodjaev R., Khachaturov A., Tosheva S. The impact of tourism and financial development on energy consumption and carbon dioxide emission: Evidence from Post-communist Countries. Journal of the Knowledge Economy. 2021. DOI: 10.1007/s13132-021-00732-x

66. Maddala G. S., Wu S. A comparative study of unit root tests with panel data and a new simple test. Oxford Bulletin of Economics and Statistics. 1999;61(S 1):631-652. DOI: 10.1111/1468-0084.0610s1631

67. Choi I. Unit root tests for panel data. Journal of International Money and Finance. 2001;20(2):249-272. DOI: 10.1016/S 0261-5606(00)00048-6

68. Şahin B. Pazar Odaklilik Bileşenlerinin Firma Performansina Etkileri: Ankara'da Faaliyet Gösteren Startuplar Üzerine Bir Uygulama. Business \& Management Studies: An International Journal. 2018;6(2):675-693. DOI: 10.15295/bmij.v6i2.274

69. Pesaran M.H., Shin Y., Smith R.J. Bounds testing approaches to the analysis of level relationships. Journal of Applied Econometrics. 2001;16(3):289-326. DOI: 10.1002/jae.616

70. Engle R.F., Granger C.W.J. Co-integration and error correction: Representation, estimation, and testing. Econometrica. 1987;52(2):251-276. DOI: 10.2307/1913236

71. Johansen S. Statistical analysis of cointegration vectors. Journal of Economic Dynamics and Control. 1988;12(23):231-254. DOI: 10.1016/0165-1889(88)90041-3

72. Johansen S., Juselius K. Maximum likelihood estimation and inference on cointegration - with applications to the demand for money. Oxford Bulletin of Economics and statistics. 1990;52(2):169-210. DOI: 10.1111/ j.1468-0084.1990.mp52002003.x

73. Ozturk I., Acaravci A. The causal relationship between energy consumption and GDP in Albania, Bulgaria, Hungary and Romania: Evidence from ARDL bounds testing approach. Applied Energy. 2010;87(6):1938-1943. DOI: $10.1016 /$ j.apenergy.2009.10.010

74. Akinci M., Akinci G. Y., Yilmaz Ö. The relationship between central bank independence, financial freedom, and economic growth: A Panel ARDL bounds testing approach. Central Bank Review. 2015;15(3):1-14. URL: https://www.tcmb.gov.tr/wps/wcm/connect/71d3762e-6bb5-4cd1-937a-210966ca0424/Sep15-1.pdf? CACH EID=ROOTWORKSPACE-71d3762e-6bb5-4cd1-937a-210966ca0424-m3fB 70z\&MOD=AJPERES

75. Piotroski J.D. Value investing: The use of historical financial statement information to separate winners from losers. Journal of Accounting Research. 2000;38(Suppl.):1-41. DOI: 10.2307/2672906

\section{ABOUT THE AUTHOR / ИНФОРМАЦИЯ ОБ АВТОРЕ}

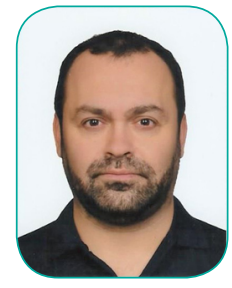

Bilgehan Tekin - PhD, Assoc. Prof. Dr., Faculty of Economics and Administrative Sciences, Department of Business and Finance, Çankırı Karatekin University, Çankiri, Turkey Бильгехан Текин - PhD, доцент, факультет экономики и административных наук, кафедра бизнеса и финансов, Университет Чанкыры Каратекин, Чанкыры, Турция bilgehantn@outlook.com

The article was submitted on 02.06.2021; revised on 16.06.2021 and accepted for publication on 27.09.2021. The author read and approved the final version of the manuscript.

Статья поступила в редакцию 02.06.2021; после рецензирования 16.06.2021; принята к публикации 27.09.2021.

Автор прочитал и одобрил окончательный вариант рукописи. 
APPENDIX

The REITs used in the study

\begin{tabular}{|c|c|c|c|}
\hline \multicolumn{2}{|c|}{ Springate } & \multicolumn{2}{|c|}{ Altman } \\
\hline Stock Code & T-REIT Name & Stock Code & T-REIT Name \\
\hline AKMGY & Akmerkez REIT & AKSGY & Akiş REIT \\
\hline ALGYO & Alarko REIT & AKMGY & Akmerkez REIT \\
\hline ATAGY & Ata REIT & ALGYO & Alarko REIT \\
\hline AGYO & Atakule REIT & ATAGY & Ata REIT \\
\hline DZGYO & Deniz REIT & AGYO & Atakule REIT \\
\hline DGGYO & Doğuş REIT & AVGYO & Avrasya REIT \\
\hline ISGYO & İş REIT & DZGYO & Deniz REIT \\
\hline MRGYO & Martı REIT & DGGYO & Doğuş REIT \\
\hline NUGYO & Nurol REIT & ISGYO & İş REIT \\
\hline OZGYO & Özderici REIT & NUGYO & Nurol REIT \\
\hline RYGYO & Reysaş REIT & OZGYO & Özderici REIT \\
\hline SNGYO & Sinpaş REIT & PEGYO & Pera REIT \\
\hline TRGYO & Torunlar REIT & RYGYO & Reysaş REIT \\
\hline TSGYO & TSKB REIT & SNGYO & Sinpaş REIT \\
\hline VKGYO & Vakıf REIT & TSGYO & TSKB REIT \\
\hline YKGYO & Yapı Kredi Koray REIT & VKGYO & Vakıf REIT \\
\hline YGYO & Yeşil REIT & YKGYO & Yapı Kredi Koray REIT \\
\hline
\end{tabular}

Source: developed by the author. 


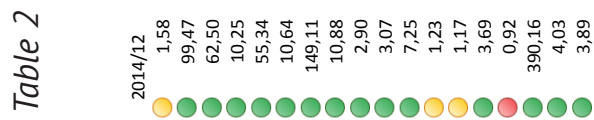

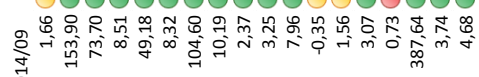
N000000000000000000

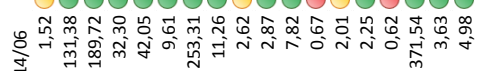
嵌 000000000000000000

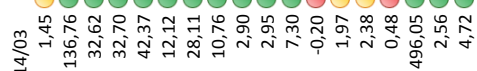
ते 000000000000000000

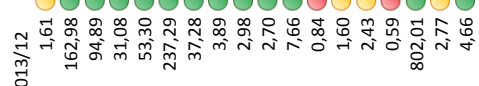
స000000000000000000

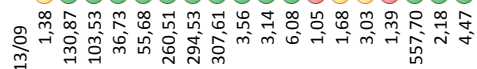
î.000000000000000000

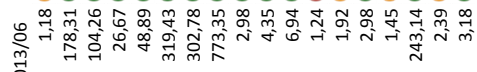
究

N 000000000000000000

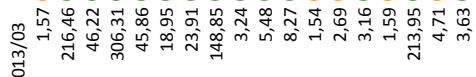
वें000000000000000000

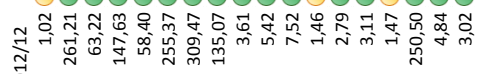
वें 100000000000000000

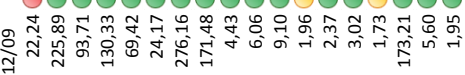
จำ 000000000000000000

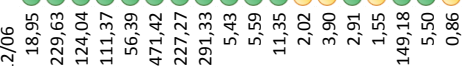

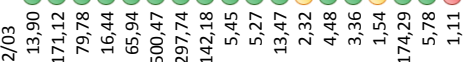

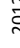

000000000000000000

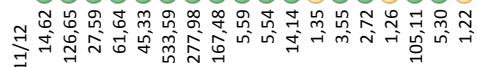

耐

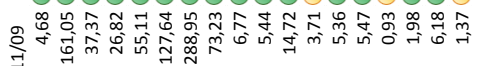
i⿱

¿ 000000000000000000

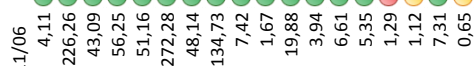
त्रु

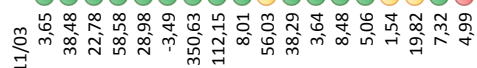
ज्ञ

N000000000000000000

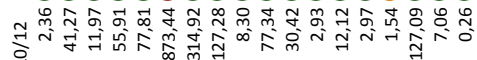
वें N000000000000000000

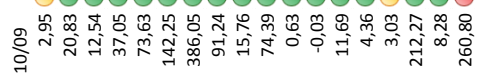
ते 000000000000000000

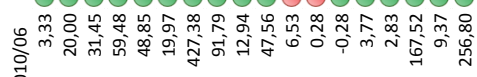
: 000000000000000000

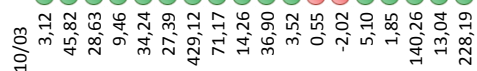
तें000000000000000000

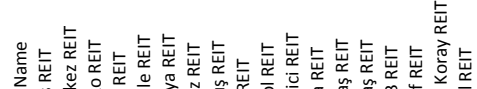

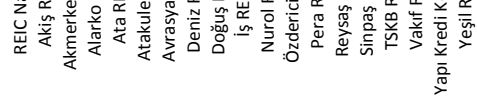

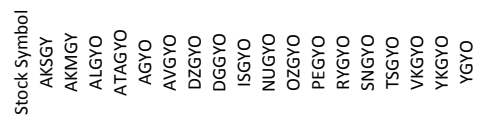

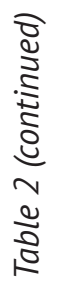

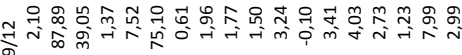
今.000000000000000000

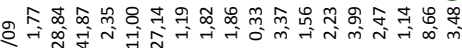
वे

00000000000000000

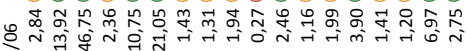
वें N000000000000000000

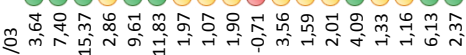
वे.

N000000000000000000

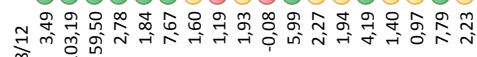
㐫 000000000000000000

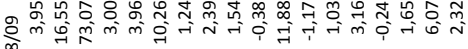
㐫 000000000000000

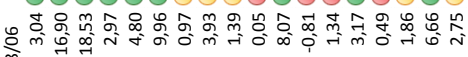
离

000000000000000000

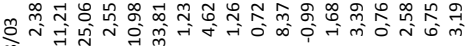
$\stackrel{\text { ) }}{\infty}$ 00000000000000000

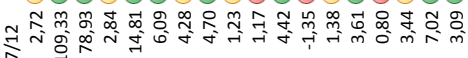


(1)

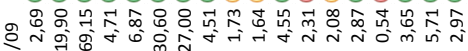
今े N000000000000000000

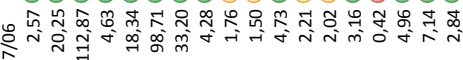

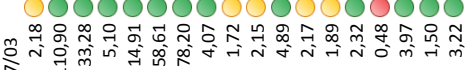
今ิ N000000000000000000

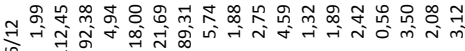
000000000000000000

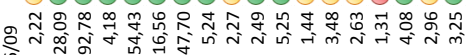
:

000000000000000000

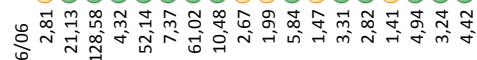

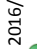
000000000000000000

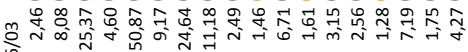
गे

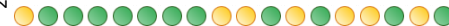
₹ पे 000000000000000000

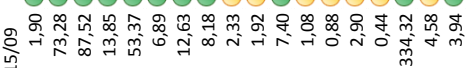
वृ.

(000000000000000000

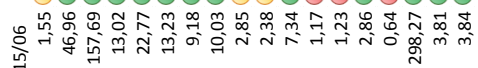
ते

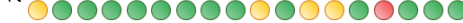

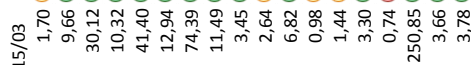
药000000000000000000

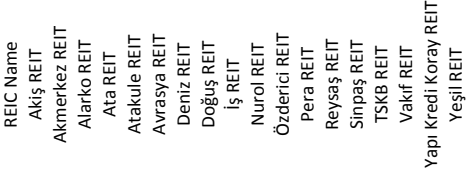

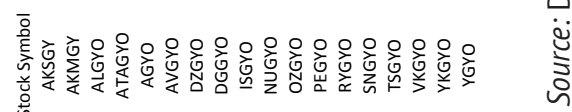


$\frac{m}{\frac{m}{0}}$

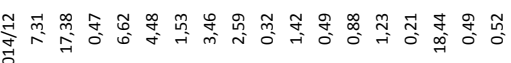

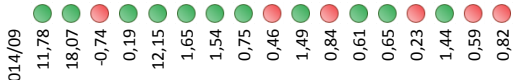

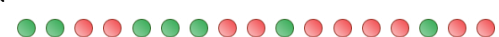

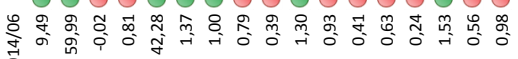

00000000000000000

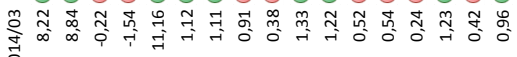

0000000000000000

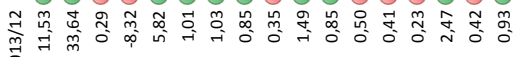
0000000000000000

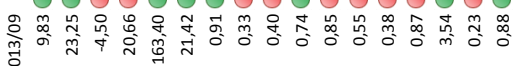
000000000000000

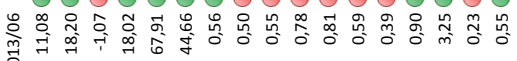
0000000000000000

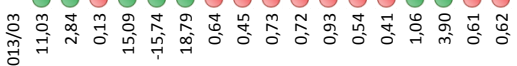
0000000000000000

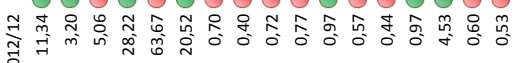
000000000000000

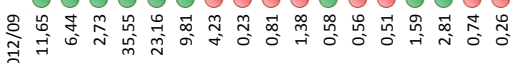
00000000000000000

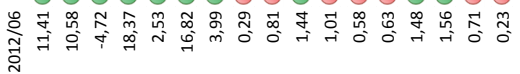

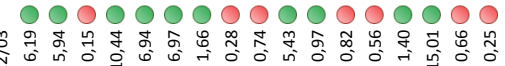
000000000000000

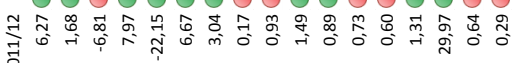
0000000000000000

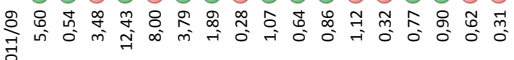
0000000000000000

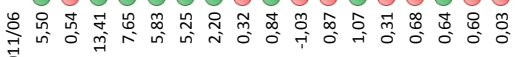

0000000000000000

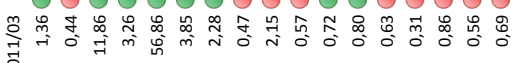

0000000000000000

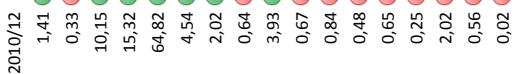

000000000000000

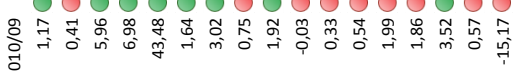

0000000000000000

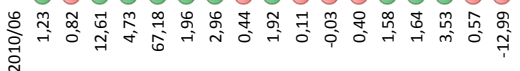

0000000000000000

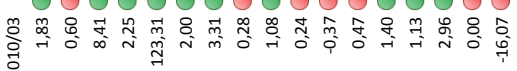

00000000000000000

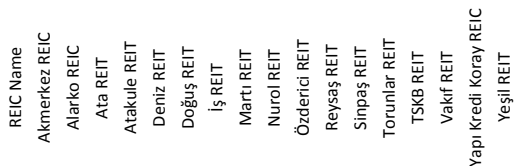

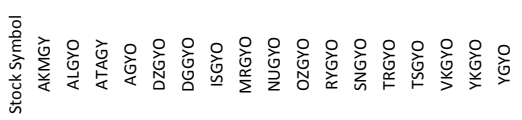

突

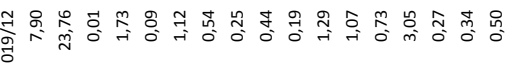

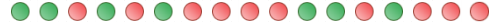

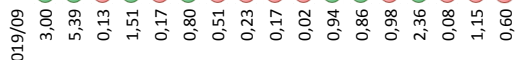

0000000000000000

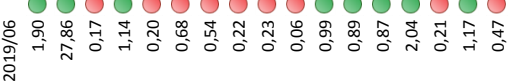
00000000000000000

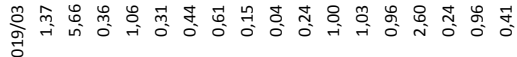
00000000000000000

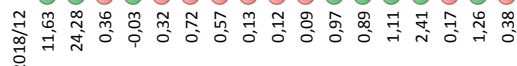
0000000000000000

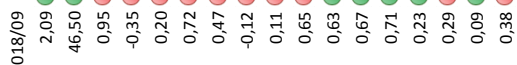
000000000000000

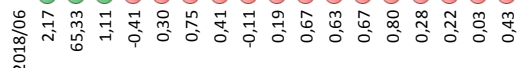
0000000000000000

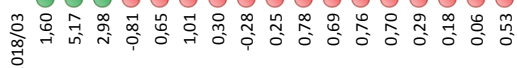
000000000000000

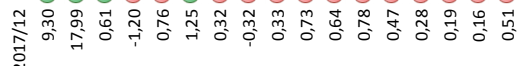
000000000000000

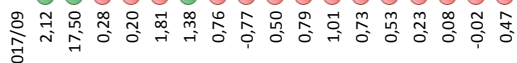
0000000000000000

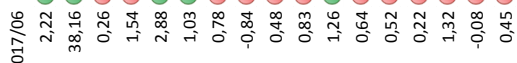

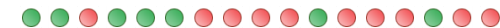

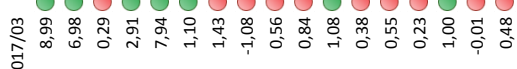
00000000000000000

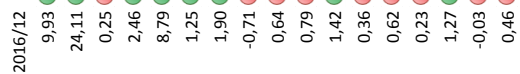
00000000000000000

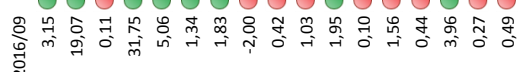

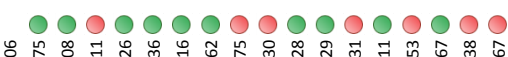

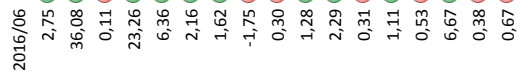
0000000000000000

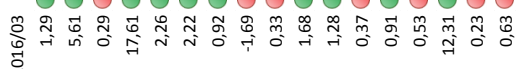
00000000000000000

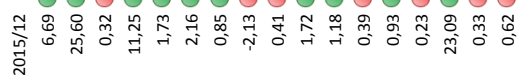
0000000000000000

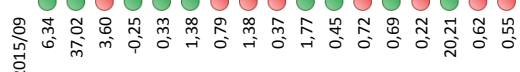
00000000000000000

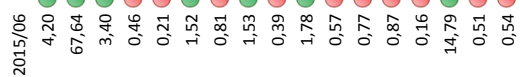

0000000000000000

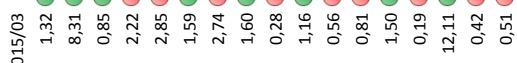

0000000000000000

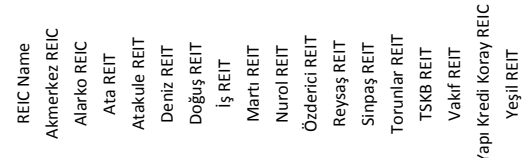

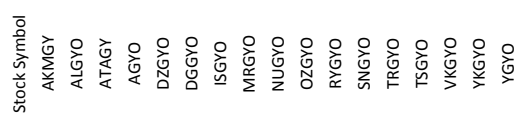

